\title{
Modelling the perception of security in the Covid-19 era
}

\section{Modelando la percepción de seguridad en la era Covid-19}

Cruz García Lirios ${ }^{1}$, Jorge Hernánez Valdés ${ }^{2}$, María del RosarioMolina González ${ }^{3}$

${ }^{1}$ https://orcid.org/0000-0002-9364-6796. Universidad Autónoma del estado de México. ${ }^{2}$ https://orcid.org/000-0001-6490-0479. Universidad Autónoma del estado de México. ${ }^{3}$ https://orcid.org/0000-0001-6016-3889 . Universidad de Sonora.

\section{DOI: https://doi.org/10.46589/rdiasf.vi36.411}

Recibido 26 de agosto 2021.

Aceptado 3 de octubre 2021

Publicado 01 de noviembre 2021

\begin{abstract}
The objective of this work was to provide empirical validity to the Security Perception Scale. A crosssectional, correlational and psychometric study was conducted with a selection of 100 students. He suspects his participation in local crime prevention programs. Seven dimensions were established: territorial, national, public (government), human, public (self-protection), private and international, although the research design limited the results to the sample surveyed, suggesting the extension of work to other aspects of public insecurity .
\end{abstract}

Keywords: Covid-19, Reliability, Validity, Security.

\section{Resumen}

El objetivo de este trabajo fue dar validez empírica a la Escala de Percepción de Seguridad. Se realizó un estudio transversal, correlacional y psicométrico con una selección de 100 estudiantes. Sospecha de su participación en programas locales de prevención del delito. Se establecieron siete dimensiones: territorial, nacional, pública (gobierno), humana, pública (autoprotección), 
privada e internacional, aunque el diseño de la investigación limitó los resultados a la muestra encuestada, sugiriendo la extensión del trabajo a otros aspectos de la inseguridad pública.

Palabras clave: Covid-19, Confiabilidad, Validez, Seguridad.

\section{Introduction}

Security, in several countries, have been suffered a lack, or absence, particularly when it is talked about governmental participation. Public security can be understood it as the state labor to protect and safe its population from internal dangers or threats. In Latin-American countries, public safe keeping is perceived as absent, due to big amount of press coverages which exposes mentioned lack (Rincon et al., 2018).

In case of Mexico, day by day, they appear in the news, a bigger quantity of red notes' coverages, which shows a violent face of the country (Bustos et al., 2018). Public safety events occur throughout the world, posing a threat to personal safety, property and national defense. Mexico's security problems are similar to the general context in Latin America in many ways. However, Mexico has an influence of organized crime due to the levels of consumption of illegal products in the US market. UU (Carreon et al., 2018).

Public security has traditionally been understood as the function of the State that consists in protecting its citizens from illegal attacks on (or crimes against) their property, physical integrity, sexual freedom, etc. The meaning of public safety is inferred as security of persons: inherence, inseparability, breadth and focus on justice (Aldana et al., 2018).

It is stated that our reality's perception is subjective and that our world's perception depends of our life conditions. Perception of reality operates from a superior order, from a mesosystem that would include both (perception and reality), and in which each appear like elements and not like closed and independent units. The notion that: what we see, might not be what is truly there, has 
troubled and tantalized, all the population in every sector, class, or roll of our society. Different population's sector would have different perception of security (Carreon et al., 2018).

It can also be mentioned that cultural stigma in the country, also affects and promotes a lack of public safe keeping, due to the general manner of Mexican population's thinking, which in comparison with other cultures, appear to be like sluggish and with a short interest to develop in academic, professional, social, among other aspects. The administration of public security is the implementation of public policies that justify the guidance of the State in the prevention of crime and the administration of justice, but only the citizens' distrust of government action is evidenced by a growing perception of insecurity reported in the literature in seven dimensions: territorial, national, public (government), human, public (self-protection), private and internaut (Martinez et al., 2018).

Mexico can be seen from diverse scopes like economic, historic, or social. In that sense, there exist other sub-scopes (or sub-scales in the social scope) like health, public security, education, environmental consciousness, among others. As mentioned before, different population's sectors have different perception of social sub-scopes (or sub-scales). In case of bachelor's students, as its scholar formation gives the chance to generate critic manner of thinking, that population's sector can generate a solid perception of factor that affects society's context (Garcia et al., 2017a).

Security have concern authorities and civil society during last years. Different society's substrates have different perceptions on security.

Objective of present work is to establish the reliability and validity of an instrument that measures the perception of security in: Territorial security; National security; Public safety (State as general attorney); Human security; Public safety (Self-protection); Private security; and, internaut perception of safety, scopes (Garcia, 2021). Present document explores reliability and validity of an instrument which measures security perception in bachelor's students by reviewing seven dimensions: territorial, national, public (government), human, public (self-protection), 
private and internaut. Accordingly, setting values and residual permitted to accept the null hypothesis significant relationship between the theoretical dimensions with respect to the weighted factors.

What are the factors underlying the measurement of the perception of security in its various forms?

The theoretical relationships between safety perceptions are consistent with the observed data

\section{Method}

The experimental design consists of a non-experimental, exploratory and transversal study. The sample was made with a non-random selection of 320 students $(\mathrm{M}=21.3 \mathrm{SD}=2.1$ age and $\mathrm{M}=9$ '865.23 SD = 345.32 monthly income) in a public university in the State of Mexico. $44 \%$ are women and $66 \%$ are men.

$50 \%$ of surveyed people are under 18 years $(M=17.29$ and $S D=1.24), 40 \%$ are between 18 and 22 years $(M=20.14$ and $S D=2.36)$ and $10 \%$ more 22 years $(M=23.25$ and $S D=4.36) .30 \%$ admitted less than 3'500 pesos $(M=3 ' 200$ and $S D=123.25), 25 \%$ between 3'500 and 7'000 monthly $\left(M=5^{\prime} 467\right.$ and $\left.S D=345.25\right)$ and $45 \%$ enter more than 7'000 monthly $\left(M=8^{\prime} 913\right.$ and $S D=135.47)$.

Because the project derives from agreements between the public university and security agencies of the State of Mexico, the total universe of students was used in order to contribute to the evaluation of the program.

Scale perception of insecurity was constructed which includes 280 reagents perception around security: territorial, national, public (government), human, public (self-protection), private and internaut (Bustos et al., 2021). 
Subscale perception of territorial security. Refers to expectations about the state as rector of the public peace (Mendoza et al., 2017). It includes four reagents respond with any of six response options: $0=$ "not at all likely" to $5=$ "very likely".

Subscale perception of national security. Refers to expectations concerning the State as procurator of offenses against democracy, national identity or the interests of the population (Garcia et al., 2017b). It includes four reagents respond with any of six response options: $0=$ "not at all likely" to 5 = "very likely".

Subscale perception of public safety. Expectations regarding the allusive the state as general attorney (Juarez et al., 2017). It includes four reagents that are answered with any of six response options: $0=$ "not at all likely" to $5=$ "very likely".

Subscale perception of human security. Refers to the expectations generated before the crime prevention policies, the administration of justice and the promotion of social peace (Quintero et al., 2017). It includes four reagents respond with any of six response options: $0=$ "not at all likely" to 5 = "very likely".

Subscale perception of public security. It refers to the expectations that citizens generated from the State distrust and alienation with its security institutions, while interest focuses on civil remedies for self-protection (Carreon et al., 2017c). It includes four reagents respond with any of six response options: $0=$ "not at all likely" to $5=$ "very likely".

Subscale perception of private security. It refers to civil society expectations generated from the State as unable to prevent crime and fight corruption (Garcia et al., 2016). It includes four reagents that are answered with any of six response options: $0=$ "not at all likely" to $5=$ "very likely".

Subscale Internaut perception of safety. It refers to the expectations that Internet users consider generated from the state spy your search for information, content selection and dissemination of 
topics (Mejia et al., 2016). It includes four reagents that are answered with any of six response options; $0=$ "not at all likely" to 5 = "very likely".

Delphi technique was used to establish the homogeneity of the concepts in the reactants. We surveyed the exhibition in the lobby of the library of his university (Molina et al., 2021). Data were processed with Statistical Analysis Package for Social Sciences (SPSS for its acronym in English) and Structural Analysis of Moments (AMOS for its acronym in English). 18,0 versions. Reliability with Cronbach's alpha, validity test Bartlett, KMO and factorial weight was estimated.

Cronbach's alpha was estimated to establish the internal consistency of the overall scale and subscales. Bootstrap parameter was calculated to set the sampling when it is not possible to fully utilize the data and only a portion of the distribution is used. Adequacy and sphericity with parameters Kayser Meyer Olkin and Bartlett's test were calculated. An exploratory factor analysis with principal axes promax rotation and obliquity criterion was performed. The test of the hypothesis was made with the estimation of the parameters of adjustment and residual.

A second study was conducted with 89 merchants from a locality with a high index of public insecurity, considering their participation in the prevention of crime and the employment of private security. The same scale was used, and the information was processed with the same software and parameters.

\section{Results}

Internal consistency, according to data collection and analysis, in overall scale (0.793) and the subscales F1 = Perception of territorial security (alpha of 0.792 and $17 \%$ of the total variance explained); F2 = Perception on national security (alpha of 0.709 and $13 \%$ of the explained variance); F3 = Perception of public safety (alpha of 0.785 and $10 \%$ of the variance explained); F4 = Perception of human security (alpha of 0.782 and $7 \%$ of the explained variance); F5 = Perception of public security (alpha of 0.792 and $4 \%$ of the explained variance); F6 = Perception private security (alpha of 0.794 and $2 \%$ of the explained variance); and F7 = Perception internaut 
safety (alpha of 0.731 and $1 \%$ of the explained variance) is discrete because evidence the differences between the contexts of study in which security was conceptualized (see Table 1).

Table 1. Descriptive instrument

\begin{tabular}{|c|c|c|c|c|c|c|c|c|c|c|}
\hline $\mathrm{R}$ & $\mathrm{M}$ & $\mathrm{SD}$ & $\mathrm{A}$ & $\mathrm{F} 1$ & $\mathrm{~F} 2$ & $\mathrm{~F} 3$ & $\mathrm{~F} 4$ & $\mathrm{~F} 5$ & $\mathrm{~F} 6$ & $\mathrm{~F} 7$ \\
\hline $\mathrm{r} 1$ & 4.54 & 1.32 & .752 & .652 & & & & & & \\
\hline $\mathrm{r} 2$ & 4.82 & 1.90 & .783 & .563 & & & & & & \\
\hline r3 & 4.65 & 1.78 & .793 & .503 & & & & & & \\
\hline r4 & 4.10 & 1.56 & .702 & .451 & & & & & & \\
\hline r5 & 4.32 & 1.43 & .752 & & .603 & & & & & \\
\hline $\mathrm{r} 6$ & 4.89 & 1.32 & .751 & & .621 & & & & & \\
\hline r7 & 4.53 & 1.01 & .763 & & .573 & & & & & \\
\hline r8 & 4.21 & 1.34 & .789 & & .603 & & & & & \\
\hline r9 & 4.32 & 1.56 & .709 & & & .521 & & & & \\
\hline r10 & 4.03 & 1.89 & .742 & & & .632 & & & & \\
\hline r11 & 4.54 & 1.42 & .705 & & & .563 & & & & \\
\hline r12 & 4.31 & 1.56 & .703 & & & .511 & & & & \\
\hline r13 & 4.49 & 1.08 & .756 & & & & .438 & & & \\
\hline r14 & 4.06 & 1.78 & .721 & & & & .523 & & & \\
\hline r15 & 4.02 & 1.54 & .798 & & & & .403 & & & \\
\hline r16 & 4.01 & 1.67 & .754 & & & & .398 & & & \\
\hline r17 & 4.32 & 1.21 & .732 & & & & & .407 & & \\
\hline r18 & 4.39 & 1.31 & .709 & & & & & .532 & & \\
\hline r19 & 4.52 & 1.45 & .762 & & & & & .612 & & \\
\hline r20 & 4.61 & 1.90 & .793 & & & & & .594 & & \\
\hline r21 & 4.09 & 1.43 & .704 & & & & & & .562 & \\
\hline r22 & 4.53 & 1.32 & .783 & & & & & & .632 & \\
\hline r23 & 4.66 & 1.56 & .705 & & & & & & .458 & \\
\hline
\end{tabular}




\begin{tabular}{|c|c|c|c|l|l|l|l|l|l|c|}
\hline r24 & 4.76 & 2.67 & .763 & & & & & & .542 & \\
\hline r25 & 4.32 & 1.87 & .762 & & & & & & & .546 \\
\hline r26 & 4.41 & 1.56 & .782 & & & & & & & .687 \\
\hline r27 & 4.89 & 1.89 & .772 & & & & & & & .603 \\
\hline r28 & 4.70 & 1.46 & .794 & & & & & & & .521 \\
\hline
\end{tabular}

Note: Elaborated with data study. $\mathrm{R}=$ Reactive, $\mathrm{M}=$ Mean, $\mathrm{SD}=$ Standard Deviation, $\mathrm{A}=\mathrm{Alpha}$ Crombach excluded value item, Method: Principal Axes, Rotation: Promax. KMO = .745, Adequation $\chi^{2}=13,23$ (23df) $\mathrm{p}<.05$. F1 = Perception Territorial Security, F2 = Perception National Security, F3 = Perception Public Safety, F4 = Perception Human Security, F5 = Perception Public Security, F6 = Perception Private Security, F7 = Perception Internaut Security.

A second study, once the factors were established, possible and associative linear relationships were estimated to investigate the emergency of a second order factor common to the seven firstorder factors found (see Table 2).

Table 2. Relations between factors

\begin{tabular}{|c|c|c|c|c|c|c|c|c|c|c|c|c|c|c|}
\hline & $\mathrm{F} 1$ & $\mathrm{~F} 2$ & $\mathrm{~F} 3$ & $\mathrm{~F} 4$ & $\mathrm{~F} 5$ & $\mathrm{~F} 6$ & $\mathrm{~F} 7$ & $\mathrm{~F} 1$ & $\mathrm{~F} 2$ & $\mathrm{~F} 3$ & $\mathrm{~F} 4$ & F5 & F6 & F7 \\
\hline F1 & 1.00 & & & & & & & 1.87 & .43 & .43 & .57 & .52 & .65 & .53 \\
\hline F2 & $.54^{*}$ & 1.00 & & & & & & & 1.86 & .56 & .65 & .36 & .57 & .46 \\
\hline F3 & $.43^{* *}$ & $.53^{*}$ & 1.00 & & & & & & & 1.96 & .43 & .37 & .54 & .65 \\
\hline F4 & $.57^{*}$ & $.47^{*}$ & $.46^{*}$ & 1.00 & & & & & & & 1.86 & .46 & .47 & .57 \\
\hline F5 & $.67^{* *}$ & $.43^{* *}$ & $.52^{*}$ & $.65^{*}$ & 1.00 & & & & & & & 1.85 & .65 & .67 \\
\hline F6 & $.62^{* * *}$ & $.36^{*}$ & $.37^{*}$ & $.63^{* * *}$ & $.57^{*}$ & 1.00 & & & & & & & 1.74 & .54 \\
\hline F7 & $.43^{*}$ & $.47^{*}$ & $.58^{* *}$ & $.54^{*}$ & $.58^{* *}$ & $.64^{*}$ & 1.00 & & & & & & & 1.84 \\
\hline
\end{tabular}

Note: Elaborated with data study. F1 = Perception Territorial Security, F2 = Perception National Security, F3 = Perception Public Safety, F4 = Perception Human Security, F5 = Perception Public Security, F6 = Perception Private Security, F7 = Perception Internaut Security.

The values of the adjustment and residual parameters $\int \chi^{2}=135.34(32 \mathrm{gl}) \mathrm{p}=0.054$; GFI $=$ 0.995; $\mathrm{CFI}=0.990 ; \mathrm{RMSEA}=0,003 \mathrm{~J}$ suggest the non-rejection of the null hypothesis relative to 
the significant differences between the theoretical relationships established in the literature with respect to the empirical relationships found in the study (see Figure 1).

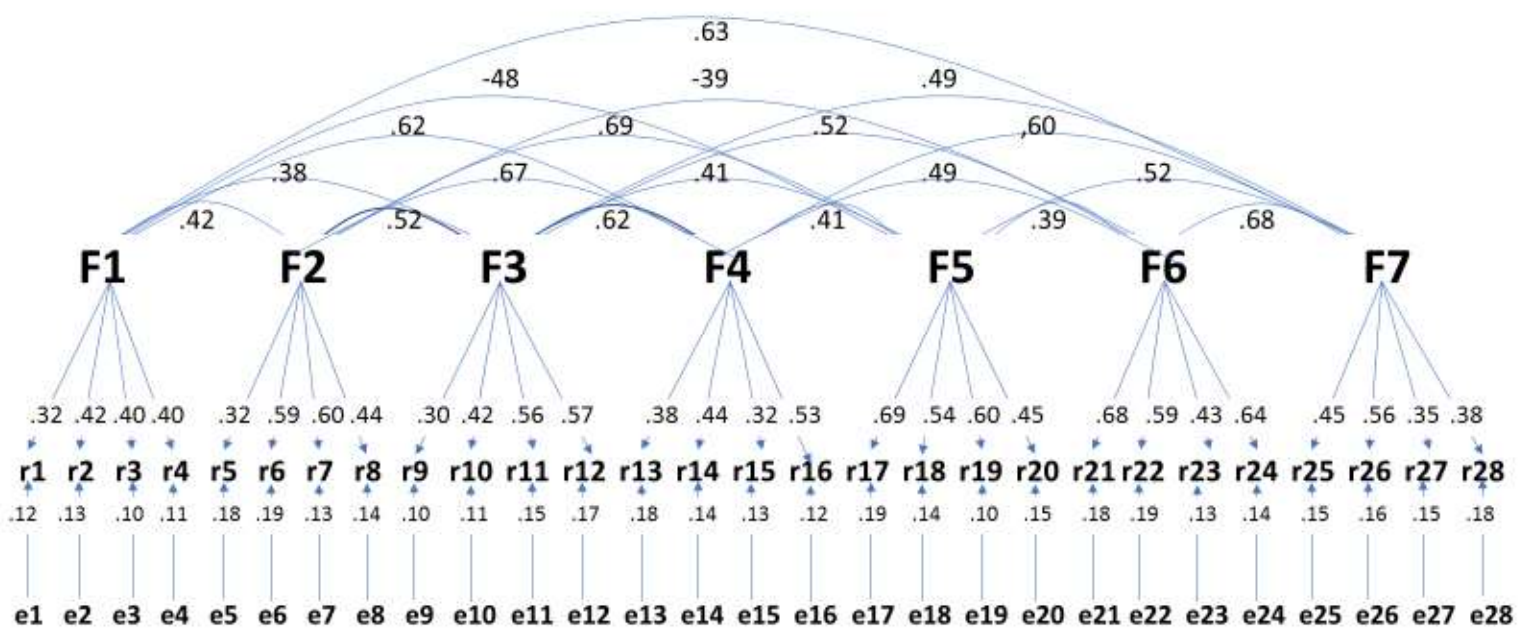

Figure 1. Structural equation modelling

Note: Elaborated with data study. $\mathrm{R}=$ Reactive, $\mathrm{F} 1$ = Perception Territorial Security, F2 = Perception National Security, F3 = Perception Public Safety, F4 = Perception Human Security, F5 $=$ Perception Public Security, F6 = Perception Private Security, F7 = Perception Internaut Security, e = Error measurement indicator

\section{Discussion}

The contribution of the present work to the state of the matter lies in the validity of an instrument that measures the perception of security, although the design limits the results to the context of the investigation, it is suggested to extend the work to other common scenarios. The validity of the instrument will contribute to the evaluation of security policies, crime prevention programs and the reconstruction of civil confidence with respect to the performance of its authorities.

In the field of public security administration, it is necessary to have validated instruments to establish the evaluation of policies, programs and strategies for crime prevention, citizen 
confidence and performance of the authorities, although the instrument can be implemented to other organizations dedicated to Private security

In Mexico, a common interpretation or idea of which country is lacking security prevails. The absence of custody is influenced by the presence of organized crime, the illegal sale of drugs and weapons and the corruption available in each branch of government, among the main aspects.

The correlations of reliability and validity when the unit far show that there are other dimensions linked to construct. In this sense, the inclusion of self-control explains the effects of state propaganda regarding crime prevention, law enforcement and peace education on lifestyles of civilian sectors.

The contribution of this study is concerned about the reliability and validity of an instrument which measured seven dimensions of security: territorial, national, human, public, public, private and digital.

The studies on public safety identify in the government's expectations the predominant factor that explains the phenomenon as an efficient, effective and effective institution, but in the present work the emergence of this phenomenon has been demonstrated from a structure of perceptions around the personal, citizen, public, human, national and territorial agenda.

The objective of this work was to corroborate the factorial structure of perceived safety, although the research design limits the finding of the research scenario, suggests the construction of an agenda and the incidence in security policies based on opinions and expectations of the governed with respect to the performance of their rulers.

\section{Conclusion}

The objective of the present work was to model the perception of safety, considering seven dimensions reported in the literature and which, when contrasted with the observations of the present work, formed a structure that explained $54 \%$ of the total variance. In relation to the state 
of the art, the model includes the dimensions that the literature relates to security policies, although it also suggests the inclusion of another dimension related to security in social networks that would be distinguished from Internet security by the protection protocols of data. In this sense, the security agenda would lie in eight dimensions that would anticipate scenarios of conflict between the rulers and the ruled.

\section{References}

Aldana, F. J. Rosas, \& C. Garcia, C. (2018). Especificación de un modelo para el estudio de la agenda de la seguridad pública. Atlante, 9 (1), 1-20

Bustos, F. A. Ganga, B. Llamas \& M. Juarez, M. (2018). Contrastación de un modelo de decisión prospectiva e implicaciones para una gobernanza universitaria de la sustentabilidad. Margen, $89(1), 1-16$

Bustos, J. M., Garcia, C., Carreon, J., Hernandez, J. \& Juarez, M. (2021). Perception of risk among university student before the spread of the Covid-19. Medico Research Chronic, 8 (3), $1-9$

Carreon, A. V. Blanes. \& C. Garcia, C. (2018). Confiabilidad y validez de un modelo de gobernanza percibida de la inseguridad. Sin Frontera, 11 (27), 1-53

Carreon, C. Garcia \& A. V. Blanes, A. (2018). Redes de violencia en torno a la gobernanza de la seguridad pública, Ciencias Sociales, 4 (2), 60-65

Carreon, J. Hernandez \& C. Garcia, C. (2017a). Una revisión teórica para el estudio de la gobernanza de la seguridad pública. Epsys, 4 (1), 1-15

Garcia, C. (2021). Metanalisis de la seguridad percibida en el transporte público en la era Covid19. Eco Matemático, 12 (1), 120-130 
Garcia, J. Carreon \& J. Hernandez, J. (2016). Gobernanza del terror a la delincuencia. Eureka, 13 (2), 168-185

Garcia, J. Carreon, \& J. Hernande, J. (2017c). La cogestión como dispositivo de seguridad para el desarrollo sustentable local. Eureka, 14 (2), 268-289

Garcia, J. Carreon. \& J. Hernandez, J., (2017b). Gobernanza de la seguridad pública. Revisión de la literatura para una discusión del estado del conocimiento de la identidad sociopolítica delictiva. Margen, 84 (1), 1-17

Juarez, J. Carreon, M. L. Quintero, F. Espinoza, J. M. Bustos. \& C. Garcia. C. (2017). Reliability and validity of an instrument that measures dimensions a security and risk perception in student of a public university. International Journal of Advances in Social Science and Humanities, 11 (12), 23-13

Martinez, F. Anguiano. \& C. Garcia, C. (2018). Gobernance of social works towargs a network violence. Social. Science Learning Educational Journal, 6 (1), 1-3

Mejia, J. Carreon \& C. Garcia, C. (2016). Efectos psicológicos e la violencia e inseguridad en adultos mayores. Eureka, 13 (1), 39-55

Mendoza, J. Carreon, J., Mejia, S. \& Garcia, C. (2017). Especificación de un modelo de representaciones propagandísticas en adultos mayores ante la seguridad púbica. Tlatemoani, 25 (1), 21-31

Molina, M. R., Coronado, O., Garcia, C. \& Quiroz, C. Y. (2021). Contrast a model of secuurity perception in the Covid-19 era. Journal Community Medicine \& Public Health Care, 8 (1), 77 83 
Quintero, J. Hernandez, A. Sanchez, H. D. Molina. \& C. Garcia, C. (2017). Modelo de expectativas en torno a la seguridad pública en microempresarios del centro de México. Sin Frontera, 10 (26), 1-20

Rincon, M. Juarez \& C. Garcia, C. (2018). Interpretación de discursos en torno al habitus de movilidad para develar el significado del transporte público. Mar

Cómo citar:

García Lirios, C., Hernánez Valdés, J., \& Molina González, M. (2021). Modelling the perception of security in the Covid-19 era . Revista De Investigación Académica Sin Frontera: División De Ciencias Económicas Y Sociales, (36). https://doi.org/10.46589/rdiasf.vi36.411

latinde䇏 cat:loger

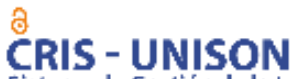

Sistema de Gestión de la Investigación

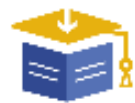

LatinREV Neliti - Indonesia's Research Repository
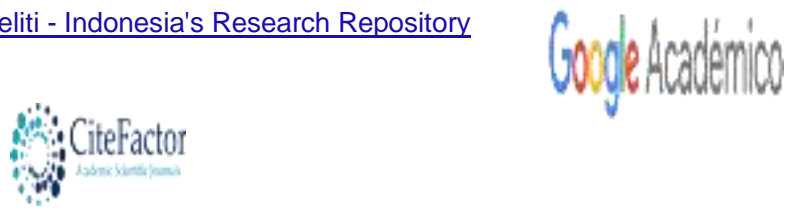

- Dialnet

IIIFACTOR
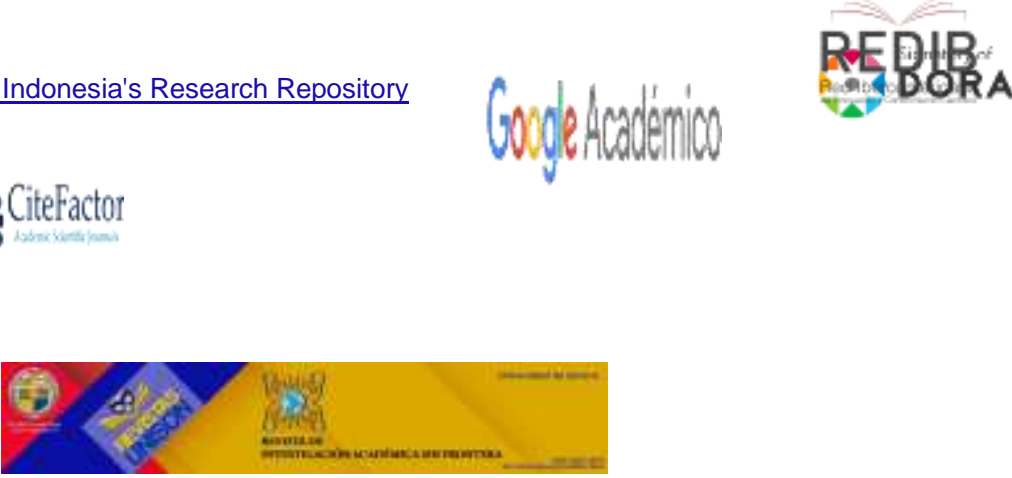